\title{
Nadbudowa matrycy mitów \\ i ich transformacje na przykładzie najnowszej twórczości chorwackich, czarnogónskich i kosowskich dramatopisarzy oraz realizatorów scenicznych ${ }^{1}$
}

Tradycja mityczna, w planie bliskim, jak również dalekim, promieniuje, przekracza granice oraz odgrywa rolę źródła inspiracji estetycznych. Jak zaznaczył Jacek Wachowski, procesy te nie są żadnym novum. Umożliwiają one od dawna tworzenie płaszczyzny porozumienia oraz łączności między kulturą nowożytną i jej antyczną przeszłością ${ }^{2}$. Dynamiczny system symboli, archetypów, obrazów oraz schematów transponowany z mitologii został trwale włączony w kulturę i intensywnie wpływa na rozwój sztuki, także w przypadku artystów aktywnych w krajach byłej Jugosławii. Mity pozostają w stadium nieustannych ewolucji, istnieją $\mathrm{w}$ wielu wariantach i generują nowe znaczenia ${ }^{3}$. Stanowią one intrygującą domenę kreacji dla współczesnych dramatopisarzy i realizatorów teatralnych w regionie postjugosłowiańskim ${ }^{4}$, zarówno w przypadku twórców o ugruntowanej pozycji, jak i reprezentantów młodszej generacji, którzy swoje propozycje artystyczne przedstawili w ciągu ostatnich kilkunastu lat.

1. Praca powstała w ramach projektu badawczego nr 2017/24/C/HS2/00436, finansowanego ze środków Narodowego Centrum Nauki.

2. Jacek Wachowski, Stowo wstępne, w: Dramat-mit-tradycja: O transtekstualności w polskiej dramaturgii współczesnej, Acarus, Poznań 1993, s. IX.

3. Tomasz Mizerkiewicz, Mitologizacje: o związkach intertekstualnych z mitologia w powieści polskiej po 1956 roku, „Pamiętnik Literacki”, 2000, XCI, z. 4, s. 83.

4. Strefa kulturowa obejmująca obszar byłej Jugosławii, złożona obecnie z siedmiu państw: Bośni i Hercegowiny, Chorwacji, Czarnogóry, Kosowa (niepodległość uznana przez 110 państw świata), Macedonii, Słowenii i Serbii. Kategoria post-Jugosławii oznacza inicjatywę kształtowania się nowej sieci między postjugosłowiańskimi państwami. Zob. Nikola Dedić, Jugoslavija u post-jugoslovenskim umetničkim praksama, „Sarajevske sveske”, 2017, nr 51 <http://sveske.ba/en/ content/jugoslavija-u-post-jugoslovenskim-umetnickim-praksama> (30.03.2018). 
Otwartość współczesnych autorów z tych obszarów wobec dziedzictwa starożytnej Grecji i Rzymu była częstym zjawiskiem u schyłku XX wieku (jeszcze $\mathrm{w}$ czasie trwania Jugosławii i tuż po jej rozpadzie). Czerpanie $\mathrm{z}$ antycznego uniwersum, oprócz wskrzeszania tradycji, miało na celu stworzenie kostiumu, który mógłby pomóc w krytycznym odniesieniu się do wydarzeń społecznych i politycznych, dokonaniu obrachunku oraz wyrażeniu w sposób zakamuflowany dezaprobaty lub sprzeciwu. Tworzenie swoistych pomostów między rytmem współczesności i pamięcią antyku było charakterystyczne np. dla twórczości tzw. młodego chorwackiego dramatu 5 . Inicjator ruchu, Miro Gavran, negował istnienie jakichkolwiek ogólnych, spajających te utwory wyznaczników, podkreślając ich programową różnorodność. Chorwacki krytyk literacki Velimir Visković doszukał się natomiast pewnych punktów wspólnych, takich jak: tworzenie relacji intertekstualnych, wykorzystywanie wzorców pozyskanych z tradycji literackiej, reinterpretacja tekstów kultury (w tym mitów), parodiowanie, farsa, trawestacja i inne ${ }^{6}$. Badaczka literatury Andrea Zlatar podkreśla, że transponowanie mitów w przypadku twórców z kręgu „młodego chorwackiego dramatu” sprowadzało się zazwyczaj do dyskredytowania działań postaci antycznych, ośmieszania wartości, które wyznają i parodiowania tragicznego efektu. W drodze transpozycji dochodziło do upodobnienia tego, co mityczne i niemityczne, historyczne i współczesne. W przeciwieństwie do przedstawicieli starszych generacji dramatopisarzy dominowały tu desemantyzacja i dewaloryzacja ${ }^{7}$.

Antycznym tworzywem literackim, $\mathrm{z}$ którego powstawały zazwyczaj nowe sploty dyskursywne i artystyczne, była dobrze znana fabuła, posiadająca ustaloną tradycję interpretacyjną oraz wywołująca w umyśle odbiorcy określone konotacje ${ }^{8}$. W opracowaniach artystycznych wśród twórców (post)jugosłowiańskich ${ }^{9}$ dostrzec można pewne dysproporcje: wybrane postaci i związane z nimi motywy pojawiają się częściej niż inne, niektóre są niezmiernie popularne, niektóre występują sporadycznie. Szczególne zainteresowanie dramatopisarzy, ale też dramaturgów, reżyserów, producentów teatralnych oraz odbiorców (czytelników, publiczności i krytyków) wzbudziły dotąd losy bohaterów mitologicznych, takich jak Antygona,

5. Gabriela Abrasowicz, Dramat ciała, ciało w dramacie. Twórczość serbskich i chorwackich dramatopisarek w latach 1990-2010, Atut, Wrocław 2016, s. 81-88.

6. Velimir Visković, Izazovi pred mladom hrvatskom dramom, w: Krležini dani u Osijeku 1995, I. knjiga, Zavod za povijest hrvatske književnosti, kazališta i glazbe HAZU: Odsjek za povijest hrvatskoga kazališta HAZU, Osijek-Zagreb, 1996, s. 124.

7. Andrea Zlatar, Antičke teme u mladoj hrvatskoj drami, w: Krležini dani..., s. 128.

8. Marzena Walińska, Mitologia w staropolskich cyklach sielankowych, Gnome, Katowice 2003, s. 34.

9. Zapis „(post)jugosłowiański” jest użyty z rozmysłem, ponieważ oznacza podwójne odwołanie zarówno do twórczości z okresu jeszcze jugosłowiańskiego, jak i tej powstającej po rozpadzie federacyjnego państwa. 
Medea, Edyp. Frekwencja najbardziej wyrazistych odwołań w dramatopisarstwie w tym makroregionie w drugiej połowie XX wieku i na początku nowego tysiąclecia prezentuje się w następujący sposób:

(1) Antygona: Drago Ivanišević (Chorwacja) - Miłość w żałobie albo Antyantygona (Ljubav u koroti ili Antiantigona, 1957), Dominik Smole (Słowenia) - Antygona (Antigona, 1960), Tonči Petrasov Marović (Chorwacja) - Antygono, królowo (Antigone, kraljice, 1981), Miro Gavran (Chorwacja) - Antygona Kreona (Kreontova Antigona,1983), Slavoj Žižek (Słowenia) - Antygona (Antigona, 2016);

(2) Ifigenia: Matko Sršen - Ifigenia (Ifigenija, 1989), Lana Šarić (Chorwacja) Ifigenia (Ifigenija, 2005);

(3) Medea: Josip Vela (Chorwacja) - Medea 1995 (Medeja 1995, 1995), Ivana Sajko (Chorwacja) - Archetyp: Medea - monolog dla kobiety, która czasami mówi (Arhetip: Medeja - monolog za ženu koja ponekad govori, 2000), Ljubomir Đurković (Czarnogóra) - Medea (Medeja, 2015); Europa: Ivana Sajko (Chorwacja) - Europa - monolog dla matki Courage i jej dzieci (Europa - monolog za majku Courage i njezinu djecu, 2004), Tanja Šljivar (Bośnia i Hercegowina) - Ja, Europa (Ja, Evropa, 2017);

(4) Dedal i Ikar: Kristina Gavran (Chorwacja) - Dedal i Ikar (2011), Ivana Sajko (Chorwacja) - Pejzaż z upadkiem (Krajolik s padom, 2011);

(5) Orestes: Tena Štivičić (Chorwacja) - Trzy zimy (Tri zime, 2014), Jeton Neziraj (Kosowo) - o.REST.es IN PEACE/Bordel Ballkan, 2015);

(6) Edyp: Milena Marković (Serbia) - Nahod Simeon (2006), Ljubomir Đurković (Czarnogóra) - Kasandra. Frazesy (Kasandra. Klišeji, 2009) i Kłamstwo Tejrezjasza (Tiresijina laž, 2010).

Na szczególną uwagę zasługują dokonania wybranych autorów i autorek, którzy posiłkując się znanymi mitami, stworzyli pokaźne cykle dramatyczne. Trylogia I bogowie cierpia (I bogovi pate) chorwackiego literata Marijana Matkovicia powstawała od okresu II wojny światowej (Prometeusz - Prometej) do końca lat pięćdziesiątych. (Powrót Heraklesa - Heraklv povratak, Dziedzictwo Achillesa Ahilova baština) i uznana została za punkt wyjścia dla chorwackiego dramatu mitologicznego XX wieku. Linię tę kontynuowała z powodzeniem między innymi przedstawicielka średniego pokolenia dramatopisarzy chorwackich Lada Kaštelan (absolwentka Akademii Sztuki Dramatycznej i filologii klasycznej), która jeszcze w czasie studiów filologicznych opracowywała dramat antyczny - tłumaczyła teksty i tworzyła własne adaptacje, które ukazały się w publikacji Przed wrotami Hadesu (Pred vratima Hada, 1993). To swoiste umiłowanie literatury greckiej zaowocowało także późniejszymi oryginalnymi sztukami autorstwa Kaštelan, 
z których wyodrębnić należy Fenicjanki (Feničanke) oraz Trylogięo Agamemnonie (Trilogija o Agamemnonu).

Determinanty, sposoby rewitalizacji mitów w ramach utworów dramatycznych i scenicznych oraz efekty takich zabiegów wciąż wzbudzają zainteresowanie badaczy. Nie ulega wątpliwości, że po jeszcze bardziej dogłębnej analizie możliwe byłoby sporządzenie pełnego katalogu tematów i postaci mitologicznych powoływanych na nowo do życia w opracowaniach postjugosłowiańskich artystów. Na potrzeby tego przeglądu obszar badawczy uległ zawężeniu - interesować mnie będą teksty, w których podobieństwo świata przedstawionego do świata mitycznego jest świadome i eksponowane, a eksploatowanie fabuł oraz posłużenie się poetyką mitu wiąże się z procesem transferu kulturowego i ma jednocześnie charakter transpozycji. Przedstawione tu utwory, które „»chcą« być czytane w odniesieniu do mitu i konstruują wyraźne sygnały zmuszające do lektury w takim kontekście" ${ }^{\prime 10}$ stanowią przejawy przekroczenia granic oraz są ewidentnymi przykładami praktyk transkulturowych.

Pojęcie transferu kulturowego zakłada, że proces przemiany kultury dokonuje się w sposób ukierunkowany jako przeniesienie określonego dobra kulturowego $\mathrm{z}$ kontekstu macierzystego do docelowego, który dzięki tej interwencji zmienia swój kształt i charakter ${ }^{11}$. Wizja takiego przepływu wiąże się między innymi z założeniami o istnieniu odrębnych kultur, których granice warunkują geopolityka i historia, a także możliwości wyizolowania oraz przemieszczenia zjawisk takich jak strategie literackie i teatralne ${ }^{12}$.

Badanie transferu kulturowego koncentruje się na udowadnianiu licznych nawiązań i fenomenów transgresji między obszarami kultury ${ }^{13}$. Transgresję utożsamić można $\mathrm{z}$ działaniami, które polegają na celowym i nieodwracalnym przekraczaniu dotychczasowych granic materialnych, społecznych i symbolicznych ${ }^{14}$. Jest ona gestem ściśle związanym $\mathrm{z}$ kreatywnymi działaniami jednostki i przejawem myślenia, które nie przystaje do uprzednio ustanowionych wzorów.

Rozprzestrzenianie się kulturowych kodów, skorelowane z dość swobodną manipulacją poszczególnymi elementami, rekonfiguracją oraz generowaniem

10. Tomasz Mizerkiewicz, Stylizacje mityczne w prozie polskiej po roku 1968, „Poznańskie Studia Polonistyczne”, Poznań 2001, s. 10.

11. Mateusz Borowski, Małgorzata Sugiera, Transfer kulturowy czy kulturowa mobilność: rekonesans teoretyczny, w: TEATR - LITERATURA - MEDIA. O polsko-niemieckich oddzialywaniach w sferze kultury po 1989 roku, red. Małgorzata Leyko, Artur Pełka, Primum Verbum, Łódź 2013, s. 44.

12. Borowski, Sugiera, Transfer..., s. 45.

13. Helga Mitterbauer, Kulturtransfer - Cultural Transfer - Transferts Culturels, za: Joanna Jabłkowska, Transfer kulturowy czy po prostu kontakty?, w: TEATR - LITERATURA - MEDIA..., s. 32.

14. Józef Kozielecki, Transgresja i kultura, Wydawnictwo Akademickie „Żak”, Warszawa 2002, s. 43. 
zupełnie nowej treści i przesłania, wpisuje się z kolei w ideę transkulturowości. Kategoria ta, popularyzowana przez niemieckiego teoretyka postmodernizmu Wolfganga Welscha, zawiera w sobie nowoczesną wizję kultury otwartej, zdolnej do anektowania i emitowania treści. Od przełomu tysiącleci w strefie postjugosłowiańskiej zarejestrować można nasilenie się praktyk, które polegają na interferencji, penetracji kultur oraz tworzeniu nowych hybrydycznych jakości. Funkcjonowanie w swoistej sieci przenikania pozwala na kreację „trzeciej przestrzeni” - nowej strefy negocjacji znaczeń i reprezentacji ${ }^{15}$, dzięki czemu kultury nie ujednolicają się, ale stają się bogatsze i bardziej zróżnicowane.

\section{Wykorzystanie sramatyki mitu \\ a transcendencja czasu i różnic kulturowych}

Przepisywanie klasycznych mitów jest usprawiedliwione i pożądane, bo każda epoka potrzebuje ich aktualizacji w nowych cywilizacyjnych ramach. Współcześni twórcy demonstrują różne stosunki do tekstu podstawowego, a ich spektrum jest dość szerokie. Przystępując do gry z tekstami, odczuwają oni potrzebę naśladowania wzoru, który dzieło reprezentuje; starają się zachować partnerstwo wobec tekstu lub żywią przekonanie o konieczności jego przekształcenia ${ }^{16}$. Ponawianie wzorów, podejmowanie dawnych tematów bez wprowadzania zmian, nie stanowi strategii preferowanej, ponieważ oznacza kreacyjną bierność, epigoństwo i dość nikły wkład w refleksję nad antyczną spuścizną kulturową. (Dramato)pisarze, zamiast skłaniać się ku renarracji lub skupiać się na funkcji ornamentacyjnej mitu, powinni doprowadzić do odrodzenia jego matrycy poprzez transgresję, potwierdzić jego żywotność i plastyczność ${ }^{17}$. O wartości utworu nie decyduje wierność w odtworzeniu fabuły, a raczej polemiczne stanowisko autora lub autorki i pomysł na wykorzystanie dynamicznego potencjału wzorca.

Propozycje artystyczne autorów takich jak Ivana Sajko z Chorwacji, Ljubomir Đurković z Czarnogóry i Jeton Neziraj z Kosowa stanowią potwierdzenie, że przywiązanie do tradycji nie musi oznaczać odtwórczej rewokacji i osłabienia skłonności innowacyjnych. Decyzja o stworzeniu tekstu dramatycznego bazującego na klasycznej treści i wprowadzaniu do niego mitycznych bohaterów nie wiąże się w tych przypadkach z powierzchowną fascynacją antykiem. Artyści deklarują związek z kanonem, stawiając sobie jednocześnie za zadanie jego przemieszczenie i progresywne nadpisanie. Tworzą oni w odniesieniu do klasyki,

15. Homi K. Bhabha, The Third Space, za: Ewa Rewers, Transkulturowość czy glokalność? Dwa dyskursy o kondycji ponowoczesnej, „Er(r)go. Teoria - Literatura - Kultura”, 2003, nr 1 (6), s. 61.

16. Wachowski, Dramat-mit-tradycja..., s. 79.

17. Mizerkiewicz, Mitologizacje..., s. 88. 
ale kontestują ją i przesuwają akcenty w przetwarzanych modelach. Jednocześnie zwracają uwagę na połączenie wielorakimi zależnościami dawnych przekazów i rzeczywistości zastanej.

W wybranych utworach autorstwa wyżej wymienionych artystów zauważalne jest dążenie do przekształcania dawnych i wciąż powtarzalnych ludzkich działań, co dokonuje się w zgodzie $\mathrm{z}$ atmosferą epoki i z intencją odczytywania nowych znaczeń. Dochodzi wtedy do przekroczenia linii podziału między epokami, obszarami geokulturowymi oraz gatunkami sztuki. W efekcie teksty dramatyczne wylewają się w sposób nieprzewidywalny z ustalonych wcześniej form i stają się amalgamatami wielu dyskursów (nie tylko literackich) oraz funkcjonują jako mobilne elementy kulturowej sieci ${ }^{18}$.

W twórczości ostatniego ćwierćwiecza stosowanie przez postjugosłowiańskich autorów takich strategii konstrukcyjnych, które polegają na artystycznym patchworku, recyklingu i intertekstualnych nawiązaniach, nie jest rzadkością. W kręgu nieszablonowych opracowań mitu wyróżnić warto utwory wspomnianych już autorów: Ivany Sajko (Chorwacja; Ulicznicy - City tour Orfeusza i Eurydyki, Medea - monolog dla kobiety, która czasami mówi, Europa - monolog dla matki Courage i jej dzieci), Ljubomira Đurkovicia (Czarnogóra; Medea, Kasandra. Frazesy, Kłamstwo Tejrezjasza) i Jetona Neziraja (Kosowo; Ranny Eneasz, o.REST.es IN PEACE/Bałkański burdel). Ogromne znaczenie ma niewątpliwie przeniesienie tych tekstów na scenę $\mathrm{w}$ formie spektakli, realizowanych na szczeblu lokalnym i regionalnym - w krajach sąsiednich. Twórczość tę charakteryzuje utrwalanie mitów oraz jednoczesne zaburzanie porządku i odchylenie od konstrukcyjnego schematu. Ivana Sajko, Ljubomir Đurković i Jeton Neziraj przybliżają jakości mityczne na poziomie innej kulturowej reprezentacji. W analizie danego tematu czy też zbioru fabuł zaczerpniętych z mitologii za przydatne uznać można wyodrębnienie funkcji charakteryzujących stosunek współczesnego tekstu dramatycznego i spektaklu do materii mitologicznej. Dominującymi rodzajami wykorzystania schematu fabularnego znanych mitów okazują się prefiguracja, transpozycja i reinterpretacja.

Dzięki technice prefiguracyjnej powstaje opowieść o zdarzeniach rozgrywających się w innej niż starożytne Grecja lub Rzym czasoprzestrzeni społeczno-kulturowej, która jednocześnie ujawnia celowe podobieństwa do wybranej historii mitologicznej ${ }^{19}$. Zazwyczaj nawiązania do mitu oznaczają swoistą żonglerkę intelektualną i wymagają od odbiorcy uważnego odbioru oraz czytania utworu w bliskości

18. Tomasz Ewertowski, Mitologiczny patchwork - strategie wspótczesne i romantyczne, w: Fantastyczność i cudowność: „homo mythicus” - mityczne wzorce tożsamości, red. Halina Kubicka, Grzegorz Trębicki, Bogdan Trocha, Uniwersytet Zielonogórski, Pracownia Mitopoetyki i Filozofii Literatury, Fabryka Reklamy Ibi, Zielona Góra 2014, s. 167.

19. John J. White, Mythology in the Modern Novel, za: Mizerkiewicz, Mitologizacje..., s. 100. 
wskazanego pierwowzoru. Autorzy stosują jednak także pewne zewnętrzne sygnały ujawniające, jaki mit będzie matrycą prefiguracyjnego użyczania sensów. Jest to zazwyczaj tytuł/podtytuł, cała sfera paratekstualna (motta, przedmowy, apendyksy) lub mitologiczne imiona postaci. Zewnętrzne wskazania dotyczące odwołania się do konkretnego, przeważnie dobrze znanego mitu, sprawiają, że czytelnik nie jest zagubiony, ale nie powinien tracić czujności. Każdy utwór realizujący strategię prefiguracji jest „rozpięty na micie” ${ }^{20} \mathrm{i}$ pozostaje $\mathrm{z}$ nim w relacji, która „przejawia się w postaci pewnego systemu analogii widocznych w losach głównych bohaterów lub w strukturze świata przedstawionego" ${ }^{21}$. W efekcie niemal każdy element ma dwa znaczenia, a raczej buduje je $\mathrm{z}$ dwóch komponentów: $\mathrm{z}$ kontekstu, w jakim znalazł się w utworze oraz z sensów przydanych mu przez intertekstualnego partnera tekstu.

Transpozycja lub przemieszczenie jest jeszcze jednym sposobem odwołania się dramatopisarzy do fabuły mitologicznej. Wybrane jej części składowe zostają zaadaptowane i poddane aktualizacji dzięki zmianie perspektywy czasowej. Poprzez renarrację, rewokację, reinterpretację czy prefigurację dramatopisarze przywołują mit lub jego fragmenty (w których nie dokonano znaczących zmian) i wmontowują je $\mathrm{w}$ inną czasoprzestrzeń. Zapożyczona historia jest $\mathrm{z}$ jakiegoś powodu istotna dla postaci działających $\mathrm{w}$ świecie przedstawionym i zostaje potraktowana jako łącznik pomiędzy przestrzenią mitologiczną a realnąą ${ }^{22}$

Choć stosunek twórców do tradycji antycznej cechuje respekt i szacunek dla starożytnych autorytetów, nie oznacza to, że obecnie nie decydują się oni na przekształcanie oraz przewartościowanie tej spuścizny. Nie brakuje opracowań reinterpretacyjnych, które - idąc „pod prąd” oryginału - zwiększają jego siłę i pole oddziaływania, a także umożliwiają nadawanie mitom odmiennych sensów lub budowanie nowych. Ich autorzy dokonują istotnych modyfikacji poszczególnych ogniw opowieści podlegających odpowiednio selekcji, rekompozycji, substytucji oraz amplifikacji. Reinterpretacje mają często charakter polemiki z mitem czy próby nowatorskiego odczytania jego przesłania. Oznaczają też zderzenie różnych rodzajów doświadczenia estetycznego: związanego ze zgłębianiem tradycji antycznej i wynikającego z orientacji kultury, w której tworzy autor lub autorka.

Wyróżnione sposoby i funkcje ewokowania motywów mitologicznych nie występują w czystej postaci, lecz są sprzężone. Potwierdzi to analityczne zestawienie najbardziej reprezentatywnych realizacji artystycznych Ivany Sajko, Ljubomira Đurkovicia i Jetona Neziraja.

20. Michał Głowiński, Mity przebrane. Dionizos, Narcyz, Prometeusz, Marchołt, labirynt, Wydawnictwo Literackie, Kraków 1994, s. 157

21. Stanisław Stabryła, Hellada i Roma. Recepcja antyku w literaturze polskiej $w$ latach 1976-1990, cyt. za: Walińska, Mitologia w staropolskich cyklach sielankowych..., s. 34.

22. Walińska, Mitologia w staropolskich cyklach sielankowych..., s. 68. 


\section{Ivana Sajko: eksperyment, fuzja \\ i wytrącanie z myślowych przyzwyczajeń}

Chorwacka autorka Ivana Sajko (ur. 1975, Zagrzeb) podejmowała wielokrotnie wyraźne próby artystycznej reanimacji mitologicznych bohaterek. Działania te potwierdzały asocjacyjność i komunikatywność zapożyczonych komponentów. W przypadku utworów, do których artystka wprowadziła Eurydykę, Medeę lub Europę, można mówić o rekonfiguracji treści zaczerpniętych z mitologii oraz zmianie tektoniki tego, co zwykło się nazywać dramatem. W strukturach jej tekstów odnaleźć można bowiem fragmenty antycznych tragedii, ale też współczesnych tekstów kultury, treści oniryczne i dydaktyczne, doniesienia medialne i biurokratyczne formuły ${ }^{23}$. Zarówno artystka, jak i kobiety, które dochodzą do głosu w jej utworach, wyrażają niezgodę na niewolnicze wpisywanie się w klasyczne ramy, a postdramatyczna aktywizacja znanych matryc unaocznia społeczne manipulacje.

Do dramatu poetyckiego Ludzie ulicy (Uličari ${ }^{24}$, 2003) wkracza znana para mitycznych bohaterów, na co wskazuje już sam podtytuł: City tour Orfeusza $i$ Eurydyki. Dzięki osadzeniu ich w postapokaliptycznych, wojennych realiach, przekształceniu wzorca oraz zastosowaniu ciekawych zabiegów kompozycyjnych, utwór można odczytać na kilku równoległych poziomach (jako sztukę o miłości, o wojnie, o zagadnieniach tożsamościowych). Główne postaci są zasadniczo bezimienne i poszukują swej roli oraz tożsamości. Wyeksponowana zostaje ONA, która funkcjonuje wstępnie jako „Eurydyka lub ktokolwiek inny” ${ }^{25}$, podczas gdy ON jest „Orfeuszem i Jej didaskaliami” ${ }^{26}$. Kobieta błądzi daleko od domu i trafia do obcej strefy miasta. Jest narażona na niebezpieczeństwo, ale jej przewodnikiem staje się ON. Przez całą ich wspólną wędrówkę ONA ma zamknięte oczy i pozostaje całkowicie zależna od mężczyzny. Przedstawiony w tekście obraz labiryntu miasta, po którym poruszają się protagoniści, uzupełniany jest w dialogach aluzjami do możliwych wydarzeń wojennych. Jednym z segmentów tekstu jest przywołany mit o Orfeuszu i Eurydyce (w okrojonej formie), w którym to zostaje jednocześnie podjęta kwestia odrzucania systemowo narzuconych ról i przyjmowania nowych. Kobieta, która nie identyfikowała się z modelem jednostki słabej i pasywnej, decyduje się na inwersję: woli utożsamiać się z Syrenami,

23. Lada Čale Feldman, Monolozi za žene koje ponekad govore, w: Ivana Sajko, Žena-bomba, Meandar, Zagreb 2004, s. 127.

24. Ivana Sajko, Uličari: City tour Orfeja i Euridike, „Kolo: časopis Matice hrvatske”, 2003, nr 4, s. 95-113.

25. Sajko, Uličari..., s. 96.

26. Sajko, Uličari..., s. 96. 
które są wprawdzie postaciami negatywnymi, ale mają moc sprawczą i okazują się zwyciężczyniami.

„Orfeusz” wywiązuje się z obietnicy i w tym momencie ich drogi muszą się rozejść. Bohaterowie zastygają przed podjęciem decyzji. Poza tą linią akcji rozciąga się przestrzeń strategii autoreferencyjnej i aktywizuje się głos dramatopisarki, która wyjaśnia w komentarzu, że jej funkcja również nie jest jednoznaczna. Można pokusić się o stwierdzenie, że Ivana Sajko działa w duchu mobilności kulturowej rozumianej jako dosłowne przemieszczanie się, ale też ujmowanej jako transpozycje rozmaitych artystycznych surowców, kodów i idei estetycznych.

Intertekstualne manipulacje, których dokonuje autorka, polegają często na jednoczesnej dekonstrukcji i konstrukcji, w rezultacie czego trzon antycznej historii zostaje ponowocześnie obudowany. Tkanka utworów z trylogii Kobieta-bomba (Žena-bomba) poprzecinana jest pasażami wywodzącymi się z klasycznych i współczesnych mitów (np. mit cyborga). Innowacje na poziomie ideowo-formalnym prowadzą do minimalizowania tradycyjnie rozumianej akcji dramatycznej oraz przeniesienia akcentu na audio-wizualną stronę tekstu. $Z$ uwagi na rozpatrywania odniesień do mitologii na uwagę zasługują pierwszy i ostatni solo-performans ${ }^{27}$ z tego zbioru: Archetyp: Medea - monolog dla kobiety, która czasami mówi i Europa - monolog dla matki Courage i jej dzieci. Skłonna do eksperymentów artystka dokonuje odważnych translokacji w obrębie dostępnego scenariusza. Dramaty bazujące na rekontekstualizacji mitów opowiadają o bohaterkach, które artykułują potrzebę działania wbrew konwenansom, zwłaszcza tym podyktowanym przez porządek intelektualny cywilizowanego świata ${ }^{28}$ oraz dyskurs patriarchalny.

Do utworu Archetyp: Medea - monolog dla kobiety, która czasami mówi (Arhetip: Medeja - monolog za ženu koja ponekad govori $\left.{ }^{29}, 2000\right)$ Ivana Sajko wprowadza uwspółcześnioną figurę znanej z mitologii barbarzynki-czarodziejki i poddaje ją dezintegracji. Postać Medei na dobre zadomowiła się w literaturze oraz sztuce ${ }^{30}$ i pewną potrzebą jest jej relatywizacja. Sajko w swej projekcji nie rekonstruuje mitu, lecz idzie jeszcze dalej - przekracza go. Szkielet antycznej tragedii Eurypidesa

27. Abrasowicz, Dramat ciała, ciało $w$ dramacie..., s. 112-115.

28. Alicja Szastyńska-Siemion, Obrazy męskości i kobiecości w Medei Eurypidesa, w: Studia interdyscyplinarne, red. Alicja Kuczyńska, Elżbieta Katarzyna Dzikowska, Acta Universitatis Wratislaviensis, Wrocław 2004, s. 12.

29. Ivana Sajko, Arhetip: Medeja - monolog za ženu koja ponekad govori, w: Žena-bomba..., s. 5-17.

30. W samym tylko XX i na początku XXI wieku do swoich literackich światów Medeę zaprosili m.in. autorki: Gertrud Kolmar - Żydowska matka (1978), Ludmiła Ulicka - Medea i jej dzieci (1996), Christa Wolf - Medea: Głosy (1996) oraz twórcy dramatów: Árpád Göncz - Węierska Medea (1976), Heiner Müller w tryptyku Gnijący brzeg. Materiaty do Medei oraz Krajobraz z Argonautami (1982), Leo Katunarić - Medea 1995 (1995), Dea Loher - Medea na Manhattanie (1999), Tom Lanoye - Mamma Medea (2001), Cherrie Moraga - Głodna kobieta: meksykańska Medea (2001), Nino Haratischwili - Moje i twoje serce. Medea (2007), Dijana Protić - Tranzycyjne After party (2010). 
wypełniony jest nowym materiałem, a problematyka poruszona w pierwowzorze zostaje przywołana przez autorkę w kontekście aktualnych przemian społecznych. Chorwacka Medea jest ucieleśnieniem współczesnego kobiecego aktywizmu, walki o prawo do dokonywania wyborów i zmian, a zwłaszcza działań przeciwko esencjalistycznym ograniczeniom i repetycjom działań zgodnych z ciążącym na kobietach wzorem archetypowej roli płciowej. W tym monologu (lub raczej polilogu) splatają się, czasem trudne do ustalenia, głosy kilku kobiet: autorki, aktorki i suflerki oraz bohaterki-żony-matki, co poszerzyło skalę artystycznej prezentacji. Autorka sugeruje w podtytule tryb odbioru tekstu - Medea to nie propozycja do realizacji scenicznej, a proza poetycka, która funkcjonuje jako zbiór notatek z odegranego już spektaklu.

Geneza zbrodni w dramacie chorwackiej autorki nie jest tak oczywista, jak w oryginale. Czynnikami usposabiającymi Medeę do dzieciobójstwa oraz uśmiercenia rywalki okazują się nie tylko zazdrość i chęć odwetu na kochankach, lecz także wrogość do infantylnej polityki i toksycznej męskiej witalności, które uosabia Jazon. Medeę można uznać za prekursorkę faktycznego zaprzeczania tradycyjnego podziału ról i dziedzictwa płci. Bohaterka współczesnego dramatu zna rytuały małżeńsko-rodowej tradycji i kulturowy paradygmat matki-dzieciobójczyni. Z jej wyznania wywnioskować można, że życiu kobiety stale towarzyszy problem z autoidentyfikacją: nie czuje się winna i nie chce być Medeą. Jest pełna obaw i nie rozpoznaje samej siebie ${ }^{31}$.

Dramatopisarka ukazuje arbitralność norm społeczno-kulturowych macierzyństwa, jednocześnie uzmysławiając odbiorcom, w jaki sposób ujarzmiane przez nie ciało Medei znacząco ogranicza rozwój jej podmiotowości. Piwnica, w której odbywa się przedstawienie (o) Medei, wywołuje skojarzenia z podpowierzchniowymi obszarami, mroczną strefą podświadomości, z której trudno jest przenieść treści na poziom widzialności i słyszalności.

Na podstawie mitycznego modelu powstała także wielopoziomowa konstrukcja dramatu autorstwa Sajko Europa - monolog dla matki Courage i jej dzieci (Europa - monolog za majku Courage i njezinu djecu $\left.{ }^{32}, 2004\right)$. W złożonej figurze głównej bohaterki - towarzyszki życia zdobywcy-imperatora - zazębiają się odległe od siebie inspiracje. Tytułowa Europa pojawia się w dramacie zarówno jako postać mitologiczna (uwiedziona i zgwałcona kobieta), jak i kontynent (topos matki-ziemi) oraz formacja polityczna (Unia Europejska), a jednocześnie jest ponowoczesną reinkarnacją brechtowskiej Matki Courage, a także wcieleniem archetypu Wielkiej Matki jako odwiecznego uosobienia macierzyństwa, życia i natury. Europa wchłania w siebie wiele porządków, między którymi można płynnie się przemieszczać. We wstępie

31. Sajko, Arhetip..., s. 9 .

32. Ivana Sajko, Europa - monolog za majku Courage i njezinu djecu, w: Žena-bomba..., s. 67-119. 
do utworu bohaterka dokonuje autoprezentacji i określa się mianem „zabytku klasy zerowej, kolebki cywilizacji, matki samotnie wychowującej dzieci, miss świata" ${ }^{33}$.

Jałowe małżeństwo, opisane jako „smutna chronologia nieprzemyślanych politycznych i zbrojnych posunięc'”34 rozczarowało kobietę, ale ostatecznie obudziło w niej niezbywalną potrzebę przekazania życiowej energii i odrodzenia się w nowej odsłonie (aktywistki i wojowniczki). Bohaterka, pozbawiona możliwości poznania pierwotnego, fizjologicznego aspektu macierzyństwa, wykazuje gotowość do urzeczywistnienia nowej, symbolicznej jego formy. Europa doświadcza procesu przejścia, jej ciało rozrasta się, tyje, puchnie i rośnie w siłę. Głód emocjonalny przekształca się w apetyt na władzę - kobieta wychodzi poza sferę domową i zaczyna pełnić służbę polityczną oraz sprawować opiekę nad swoimi dziećmi - kilkumilionową rozśpiewaną armią wojennych sierot, którą ofiarował jej Pułkownik. W utworze pojawia się szereg ewidentnych odwołań do konkretnej rzeczywistości politycznej i konstrukcji kulturowo-społecznej. Ivana Sajko daje bohaterce możliwość przekroczenia ograniczeń poprzez inwersję: kobieta znana z mitu założycielskiego Europy opartego na gwałcie ${ }^{35}$ ujeżdża i ujarzmia byka, a równolegle bezdzietna i bierna żona Pułkownika przeistacza się w wojowniczkę z armią dzieci.

Utwory zebrane w trylogii Kobieta-bomba stanowiły materiał wykorzystywany przez Ivanę Sajko podczas jej oryginalnych performansów z elementami melorecytacji, oprawą muzyczną i multimedialną, nazywanych odczytami autoreferencyjnymi. Ponadto, te trzy monologi zostały zespolone w projekcie teatralnym Archetyp: Medea/Kobieta-bomba/Europa (Arhetip: Medeja/Žena-bomba/Europa, ZKM, Zagrzeb, 2007), do którego zaproszono trzy reżyserki: Dorę Ruždjak-Podolski, Frankę Perković i samą Ivanę Sajko.

\section{Ljubomir Đurković: prześwietlanie klisz i druzgotanie znanych konstrukcji}

W karierze artystycznej Ljubomira Đurkovicia (ur. 1952, Cetinje) wyodrębnić można fazę, w której zauważalne jest inspirowanie się mitologią i słynnymi dziełami, przede wszystkim $\mathrm{z}$ dawnej literatury greckiej. Ze względu na te intertekstualne tendencje do pełniejszej recepcji jego utworów potrzebna jest

33. Sajko, Europa..., s. 69-70.

34. Sajko, Europa..., s. 85.

35. Osnową mitu jest historia uwiedzionej fałszywą łagodnością białego byka-Zeusa, uprowadzonej i zgwałconej fenickiej piękności o imieniu Europa, która urodziła władcy Olimpu dwóch synów. Zob. Gabriela Abrasowicz, Magdalena Koch, Re-wizje Europy we współczesnym dramacie chorwackim (Europa - monolog dla matki Courage i jej dzieci Ivany Sajko), w: „Miscellanea Posttotalitariana Wratislaviensia”, 2014, nr 2, red. Agnieszka Matusiak, s. 249-266. 
znajomość fundamentów kultury zachodniej cywilizacji, a zwłaszcza antycznych dramatów. Badacz literatury czarnogórskiej Jakov Sabljić określa tę strategię mianem „artystycznego recyklingu” ${ }^{36}$. W ponownym wykorzystaniu użytego już niegdyś surowca tylko pozornie chodzi o minimalizację nakładów pracy. „Ponowne pisanie klasyków” nie oznacza bowiem zachowawczego przepisywania klasycznych tematów, lecz tworzenie nowych, wywrotowych wariantów mitu i zmiany jego zakresu. Autor modyfikuje wyznaczniki dotyczące konstrukcji fabuły, a jego intencją jest włączanie dodatkowych treści. Doskonałym przykładem takiej reorganizacji i rewitalizacji mitów są teksty zebrane w trylogii Grecy $\left(G r i^{37}\right)$. Twórcza ingerencja oraz umiejętne wykorzystanie dynamiki, otwartości, łączliwości i mobilności bazowych utworów pozwala Đurkoviciowi nadać klasycznym podaniom zupełnie nowy wymiar.

Autor wykorzystuje motywy mitologiczne między innymi do wyrażenia opinii na temat zastanej rzeczywistości i jej przemian, czasem także do stworzenia satyrycznej krytyki mentalności, która w jego ocenie spowalnia rozwój społeczny. Przykładem tego jest pierwszy tekst tryptyku - Medea (Medeja ${ }^{38}$, 2015). Podtytuł utworu - komitragedia - to swoista zapowiedź serii zabiegów, które mają wywołać w odbiorcy zaskoczenie. Efekt ten osiąga dramatopisarz poprzez przesunięcie oraz odwrócenie spodziewanych sytuacji i typowych relacji znanych z kanonicznego dzieła Eurypidesa. Sam Đurković zaznacza, że jego utwór powstał w wyniku demontażu i kompilacji przekształconych fragmentów klasycznego mitu, ale został też poprzetykany elementami tekstów francuskiego dramatopisarza Jeana Anouilha i niemieckiej autorki Christy Wolf.

Medea w artystycznym opracowaniu Đurkovicia nie jest zdradzoną, mściwą zbrodniarką. Czarnogórski autor pozbawia bohaterkę patologicznych, destrukcyjnych zapędów i przedstawia ją jako troskliwą, a jednocześnie pragmatyczną żonę oraz matkę. Kobieta pragnie zadbać o przyszłość swej rodziny, ale kierują nią też ambicje polityczne. W wielu scenach Medea ujawnia swoją frywolność to partnerka, która wykonuje swoje obowiązki, ale szuka też przyjemności i bez skrępowania mówi o swoich potrzebach. W konserwatywnym środowisku jej barbarzyńskie pochodzenie, liberalna postawa i przekraczanie norm społecznych wyobcowują ją w sposób zwielokrotniony. W każdej rozmowie z Medeą ujawniają się jej intelektualna przewaga i spryt. Śmieszą ją misternie budowane fikcje, które powielają stereotypy i rozmijają się z brutalną prawdą (np. niesłuszne opiewanie czynów Argonautów i Kreona).

36. Jakov Sabljić, Ponovno napisani klasici, w: Ljubomir Đurković, Grci, Žuta kornjača, Podgorica 2015, s. 195.

37. Đurković, Grci, Žuta kornjača, Podgorica 2015.

38. Đurković, Medeja, w: Grci..., s. 7-57. 
Mit został zdegradowany i od podstaw przebudowany. W nowym wydaniu, a raczej w „prawdziwej” wersji historii, śmiertelnie chory Kreon, który stracił wiarę w bogów, ale nie w narodziny następcy tronu, szuka męża dla coraz starszej, a jednocześnie bardzo infantylnej, córki Glauki. Wybór władcy pada na Jazona, gdyż jest on doskonałym kandydatem, a jego małżeństwo z Medeą jest według lokalnego prawa nieuregulowane. Jazon kuszony perspektywą panowania nad Koryntem wykazuje lojalność wobec żony i dzieci. Medea, dostrzegając jednak przede wszystkim plusy nowego układu, akceptuje propozycję. Zaobserwować tu można odwrócenie ról - to kobieta jest zdecydowana i podejmuje inicjatywę. Jest ona jednak jednostką niewygodną i zgodnie z planem Kreona musi zostać zlikwidowana. Przebiegła i dobrze poinformowana kobieta postanawia ukarać mocarza. Historia nie kończy się jednak na śmierci Glauki i Kreona. Otruci przez niedopatrzenie synowie Jazona i Medei umierają, za co bohaterka sama postanawia wymierzyć sobie karę. Tuż przed samobójczym aktem narzuca zasady, zgodnie z którymi wykreowany ma być jej wizerunek, obowiązujący odtąd w oficjalnym przekazie. Medea sama decyduje, aby jej losy zostały nakreślone w sposób odpowiadający powszechnym oczekiwaniom, tak, aby potwierdziły działanie pewnego mechanizmu (opierającego się na triadzie odtrącenie - żal - zemsta). Autor zwraca tym samym uwagę na płynność granic między punktami takimi jak: prawda i mit lub sfera prywatna i publiczna.

Opowieść została także nasycona politycznymi elementami, przez co staje się odzwierciedleniem aktualnych, nie tylko lokalnych, wydarzeń. Đurković porusza problem tworzenia schematów i dopuszczania istnienia alternatywnych wariantów (ukutych przez uczestników, świadków, badaczy reprezentujących odrębny punkt widzenia i inaczej przetwarzających dane zdarzenie). Jednocześnie dramatopisarz podkreśla, że sztuka poddawana jest rozmaitym manipulacjom w służbie polityki, jednak należy mieć nadzieję, że moc kreacji weźmie ostatecznie górę nad grami politycznymi.

Dramat ten został przeniesiony na deski teatru dzięki wspólnemu przedsięwzięciu produkcyjnemu organizacji Eurokaz (Chorwacja) i teatru Kraljevsko pozorište Zetski dom (Czarnogóra). Premiera spektaklu Medeja w reżyserii Branka Brezovaca odbyła się w 2016 roku.

W kolejnym tekście z wyżej wymienionego zbioru - Kłamstwo Tejrezjasza (Tiresijina la $\left.z^{39}, 2010\right)$ - dramacie intryg $\mathrm{z}$ elementami o charakterze parodystycznym, autor dokonuje intertekstualnej adaptacji mitów o Edypie i Antygonie. Đurković zdecydował się na niestandardową formę organizacji materiału, i rozbił go na tylko dwa akty. Taka kompozycyjna dwudzielność jest uzasadniona, ponieważ po wydarzeniach z okresu panowania i upadku Edypa następuje zmiana rządów.

39. Đurković, Tiresijina laž, w: Grci..., s. 59-155. 
Dramat, który powstał w wyniku przeformułowania klasycznego wzorca, jest wyrazem współczesnego kryzysu zaufania do instytucji społecznych oraz stanowi odzwierciedlenie ideologicznych wojen. W celu bardziej dobitnego przedstawienia zaślepienia tłumów podążających za głosem niemoralnych przewodników, autor spiętrza fabułę, efektownie komplikuje akcję i przejaskrawia postaci.

Pierwotnie Tejrezjasz - oślepiony w młodości prorok - jest kimś egzystującym na granicy światów ${ }^{40}$, łączy w sobie prawa ludzkie i boskie. Jego fizyczna ślepota została zrekompensowana wzrokiem wewnętrznym, czyli widzeniem rzeczy przyszłych ${ }^{41}$. $Z$ tego też powodu obdarzony jest niezwykłym autorytetem. $\mathrm{W}$ podaniu to on dąży do ujawnienia prawdy i uświadamia Edypowi i Kreonowi ich błędy. W czarnogórskim dramacie Tejrezjasz jest natomiast antybohaterem kumulującym w sobie typowe ludzkie przywary, który nie stoi ponad zwykłymi śmiertelnikami. Starzec wprawdzie angażuje się bardzo w sprawy, które mogą mieć wpływ na przyszłość państwa oraz osób napiętnowanych przepowiednią, jednak wykorzystuje swoją pozycję w szerzeniu nieprawdy i oślepia elitę, a w konsekwencji lud. Wytrawny manipulator sam jest zdolny do zbrodni i popycha do niej innych. Ich słabość i ambicje przekuwa na swoją korzyść. Choć dowiaduje się od Frontisa, że mały Edyp został uśmiercony, zataja istotne fakty i poprzez kłamstwo steruje losami otaczających go ludzi, bawi się nimi. Wmawia rodzinie królewskiej, że Edyp jest synem Lajosa i Jokasty, dopuścił się więc ojcobójstwa i poślubił matkę. Zarówno antycznego, jak też na nowo powołanego do życia Edypa gubi hybris, różne są jednak ich zamiary oraz wyznawane wartości. Władca w tekście Đurkovicia jest skorumpowany, nieudolny i egocentryczny. Jego motywacją jest chęć jak najdłuższego panowania.

Autor zreinterpretował historię rodu Labdakidów, która w odświeżonym wydaniu jest pełna machinacji i nieoczekiwanych zwrotów akcji. Đurković demonstruje dość prowokacyjnie, że podstawy znanego mitu osadzone są na kłamstwach. $Z$ tego powodu wiele wątków zostało w dramacie przekształconych i ukazanych jako następstwa szantażu, plotki, niewłaściwej interpretacji. Zamiast wykorzystywania pełnej konwencji klasycznego dzieła, czarnogórski dramatopisarz decyduje się na zakłócenie jego porządku, a proponując gruntownie przebudowaną opowieść mityczną, ujawnia swój sceptycyzm wobec wielkich historii.

Cechą charakterystyczną dramatów Ljubomira Đurkovicia jest obecny w nich topos poszukiwania lub rekonstrukcji tożsamości. Osobliwym tego dowodem

40. W młodości doświadczył m.in. zmiany płci.

41. Kamila Sołtysik-Matłosz, Postać Tejrezjasza w tradycji i literaturze antycznej, „Symbolae Philologorum Posnaniensium Graecae et Latinae”, 2012, XXII, nr 1, s. 29. 
jest utwór Kasandra. Frazesy (Kasandra. Klišejił², 2009). Już jego tytuł zapowiada tryb intensywnego i świadomego powielania treści, które zmieniają rejestr oraz tracą przez to swoje oryginalne znaczenie oraz efekt. Również ten tekst Đurkovicia oparty jest na wnikliwej lekturze znanych mitów, ale w prowokacyjny sposób unowocześnionych i jednocześnie przekoloryzowanych.

Tytułowa postać, która prowadzi popularny program rozrywkowy i dąży do poznania indywidualnych skandalicznych prawd swoich gości, sygnalizuje złowróżbny - kasandryczny wydźwięk dramatu. Autor narzuca w swej propozycji konwencję telewizyjnego reality show, ale określając je precyzyjnie jako reality fiction podkreśla hybrydyczny charakter utworu.

W tekście pada stwierdzenie, że główne postaci reprezentują ciała i imiona $\mathrm{w}$ procesie tranzycji ${ }^{43}$. Tożsamości każdej z bohaterek wydają się początkowo ustalone, jednak okazuje się, że kobiety przeszły rozmaite psychosomatyczne transformacje. Opowiadają one o wydarzeniach, które destabilizowały ich konstrukcje tożsamościowe, naruszyły granice pierwiastka „Ja” czy płci społeczno-kulturowej.

Główne postaci dramatu znane z antycznych tekstów: Hippolytos, Edyp, Fedra i Narcyz podlegają konwersji. Zmuszane są przez Đurkovicia do rozmaitych przemian, adaptacji, a nawet zmiany płci i wtłaczane są w nowe role. Hipolita zakochuje się w swoim pasierbie i wchodzi z nim w relacje seksualne. Młody mężczyzna opuszcza kochankę i przemienia się w Narcyza, który zakochuje się w swojej utraconej i odnalezionej siostrze bliźniaczce. Oboje mają stać się osobami transseksualnymi, jednak operacja okazuje się dla dziewczyny śmiertelna w skutkach. Trzecia bohaterka - młoda kobieta o imieniu Edypa - nieświadomie postrzega jako obiekt pożądania własnego ojca. Zmultiplikowana Kasandra występuje w każdym wątku (jako wróżka, chiromantka, jasnowidzka) i sprawia, że te trzy linie biograficzne splatają się. Stale wywłaszczane uczestniczki show opuszczają ramy mitologii, rodziny, relacji międzyludzkich, określonych ról płciowych. Skazane na dryfowanie w rzeczywistości kreowanej i sterowanej przez przepowiednie Kasandry czują się żywe tylko w opowiadanych przez siebie historiach.

Premiera spektaklu Kasandra. Frazesy (Kasandra. Klišeji) w reżyserii Slobodana Milatovicia odbyła się 2009 roku i była owocem współpracy różnych instytucji i niezależnych artystów z regionu: Ex Ponto Festival (Słowenia), Centar za kulturu Nikola Đurković iz Kotora i TEUTA festiwal (Czarnogóra), Srpsko narodno pozorište i festiwal INFANT (Serbia), Festival MOT, Skopje (Macedonia).

42. Đurković, Kasandra. Klišeji, w: Grci..., s. 157-192.

43. Đurković, Kasandra..., s. 200. 


\section{Jeton Neziraj: interferencja, progres \\ i wytyczanie nowych ścieżek rozumowania}

Kosowski dramatopisarz i producent Jeton Neziraj swoimi ponowoczesnymi realizacjami rzuca wyzwanie opinii publicznej i łamie społeczne tabu. Artysta forsuje koncepcję kontaktu jako skutecznej metody niwelowania uprzedzeń. Projekty założyciela platformy kultury Qendra Multimedia oparte są na wymianie oraz współpracy i koncentrują się wokół takich motywów, jak wpływ polityki na sztukę, polityczne stosunki międzynarodowe, przemiany społeczne. Jego prowokacyjne, a często uznawane za obrazoburcze i antypatriotyczne propozycje potwierdzające zmianę paradygmatu tworzenia nie przyczyniły się może do istotnej zmiany układu sił władzy, ale zapamiętane zostaną jako odważne artystyczne interwencje we wspólne doświadczenia zmysłowe i zakres pamięci historycznej.

Neziraj korzysta ze współczesnych środków wyrazu, ale bazuje na dobrze znanych podaniach. W jego sztukach dwie jakości (mit i aktualne treści) nakładają się na siebie, zespalają się i ulegają wzmocnieniu. Jeden z wcześniejszych utworów kosowskiego artysty, Ranny Eneasz (Aeneas Wounded/Enea i plagosur ${ }^{44}$, 2006), powstawał równolegle z tekstem Aeneas Ghost, który stworzył kanadyjski autor Michael Devine. Te dwie propozycje, skrajnie odmienne pod względem brzmienia, stylu i podejścia do tematu, stanowią segmenty produkcji zatytułowanej Aeneas 06. Mogą one funkcjonować niezależnie lub jako połączone realizacje przy użyciu tej samej scenografii i z tą samą grupą aktorów. Projekt ten polega na zestawieniu artystycznych opracowań dotyczących historii regionu i obecnych realiów. Założeniem twórców było doprowadzenie do konfrontacji tych dwóch wartości i jednocześnie zniwelowanie powstającej między nimi luki.

Dzieło życia Wergiliusza - Eneida - posłużyło w tym przypadku jako tekst bazowy, a jego wybór był przemyślany i świadomy. W lokalnej tradycji ustnej część opowieści o dziejach Trojańczyka rozgrywa się w Ilirii, starożytnej ojczyźnie Albańczyków. Ten epicki poemat wykorzystany zostaje jako szablon, według którego sytuują się rozważania o dekonstrukcji społeczeństwa i poszukiwaniu tożsamości. Podejmowane w nim kwestie narodowościowe i kulturowe okazały się szczególnie istotne w państwie, które wkrótce miało proklamować niepodległość ${ }^{45}$. Intencją autora było przede wszystkim skłonienie odbiorców do refleksji nad aktualnym zastosowaniem tych pojęć. W tym sensie dramat jest politycznie zaangażowany, nie demonizuje jednak „Inności”, a daje obraz kosztów, jakie muszą

44. Utwór został udostępniony w wersji elektronicznej przez autora, któremu za to w tym miejscu dziękuję.

45. Kosowo jednostronnie proklamowało niepodległość w 2008 roku, nie jest ona jednak powszechnie uznawana. 
ponieść strony konfliktu. Znana historia o legendarnym protoplaście Rzymian została ukazana w krzywym zwierciadle współczesności i dotyka szerokiej gamy aktualnych problemów.

Utwór otwiera autoprezentacja Generała, który wyznaje, że regularnie zjada mapę historyczną Europy. Złożoność tego rytuału ukazana jest ze sporą dozą czarnego humoru. Zazwyczaj przy podziale na kęsy bohater respektuje dawne granice, co jest szczególnie utrudnione w przypadku małych bałkańskich krajów, jedynie pochłaniając strzępy Albanii jest mniej ostrożny. Na myśl o upadłych imperiach Generał odczuwa oprócz fizycznego dyskomfortu niezbywalny żal.

Neziraj w swym nielinearnym dramacie problematyzuje stratę i ból. W wypowiedziach bohaterów pojawia się wielokrotnie stwierdzenie, że tylko martwi są wolni od tych problemów. Szczególnie sugestywnie oddana zostaje rozpacz rozbitka Eneasza i jego przyjaciela Abdullaha B. Pozbawieni ojczyzny, zagubieni i unieruchomieni na obcej ziemi mężczyźni stracili orientację w terenie i nie są już pewni własnej tożsamości. Neziraj zderza w tekście różne porządki i zaburza związki przyczynowo-skutkowe. Eneasz trafia do nowoczesnego szpitala, gdzie okazuje się, że jego rany zadano antyczną włócznią. Pacjent twierdzi, że nie odczuwa bólu, przez co staje się jeszcze bardziej kuriozalnym przypadkiem.

Obrazy zniszczenia Troi przetkane zostały scenami, które wywołują skojarzenia z niedawnymi lub aktualnymi wydarzeniami zbrojnymi (np. dialog żołnierza z dziewczynką, porwania cywilów i wyłudzenia, wspomnienia rodziców o zaginionym synu, próby odszukania jego szczątków). Przedstawione w tej liryczno-impresjonistycznej sztuce relacje między przeszłością i teraźniejszością oraz powtarzalność destrukcyjnych działań zdecydowanie podważają oficjalne narracje dotyczące podkreślania oraz pielęgnowania odrębności narodowej i kulturowej Kosowa.

Również w utworze o.REST.es IN PEACE $\left(2015^{46}\right)$ Jeton Neziraj nie ukrywa, jaki mit jest fundamentem nowej artystycznej konstrukcji. Protagoniści kosowskiej wersji Orestei Ajschylosa są obdarzeni imionami swoich antycznych pierwowzorów oraz podobnymi cechami charakteru lub predylekcjami do określonego zachowania. Aktywizując i nadpisując popularny mit, autor buduje sugestywną paralelę między dwiema czasoprzestrzeniami: starożytną Grecją i rzeczywistością w Kosowie po roku 1999. Utwór o traumie wojennej uwalnia ładunek krytyczny i rewizjonistyczny, posiada ponadto charakter subwersywny. Neziraj przedstawia bohaterów, którzy ponoszą straty w wyniku walk i nie są świadomi, że w ich losy wpisany jest kod destrukcji. W akcję, która rozgrywa się w motelu „Balkan Express”, wprzęgnięte zostały ponadto rozważania o poszukiwaniu i konstytuowaniu tożsamości (nie tylko narodowej, ale też płciowej). Oprócz postaci zna-

46. Utwór został udostępniony w wersji elektronicznej przez autora, któremu za to w tym miejscu dziękuję. 
nych z mitologii, ale zmodyfikowanych i przerysowanych, w utworze pojawiają się „zeswojszczone” figury kobiet i żołnierzy oraz posiadające lokalny koloryt elementy. Również wprowadzone songi zgodne z poetyką turbo-folk są częścią procesu familiaryzacji i synkretyzmu kulturowego, który polega na łączeniu różnych fragmentów kultur historycznie od siebie odległych ${ }^{47}$.

Bałkański Agamemnon - zbrodniarz wojenny, powraca do domu po pokonaniu Trojan. Wpada jednak w pułapkę zastawioną przez swoją żonę Klitajmestrę (której nagie ciało zakrywa tylko burka) i jej kochanka Ajgistosa. Po tym wydarzeniu z zagranicy powraca Orestes, który chce rzekomo założyć ze swoim partnerem szkołę tańca, a szykuje się tak naprawdę do ukarania Klitajmestry. Młody mściciel podważa swoim trybem życia heteronormatywność i heroiczne ideały męskości, ale równocześnie uznaje wyższość ojcostwa nad macierzyństwem. Matkobójstwo, którego ostatecznie dopuszcza się Orestes, ściąga na niego mroczne siły. Erynie i duchy zamordowanych doprowadzają go do obłędu i popychają do kolejnego destrukcyjnego aktu.

Każdy popełniony wcześniej grzech prześladuje bohaterów, wtłacza ich w ciąg repetycji zbrodni i kar. Wyjście z tego mrocznego mikroświata i nowy początek są możliwe tylko dzięki radykalnym, oczyszczającym działaniom.

Na podstawie tej Sagi pewnej bałkańskiej rodziny powstały dwie niezależne produkcje teatralne. Pierwotny projekt $o$.REST IN PEACE, który został zrealizowany 2015 roku w Czarnogórskim Teatrze Narodowym w Podgoricy, okazał się wielkim sukcesem reżysera Stevana Bodrožy. Szerokim echem odbiła się także kosowska premiera kolejnego wariantu spektaklu zatytułowanego tym razem Bałkański burdel (Bordel Ballkan, 2017), która owiana była jednak atmosferą skandalu. Z realnym niebezpieczeństwem wiązały się wówczas protesty weteranów wojennych Armii Wyzwolenia Kosowa, którzy domagali się zdjęcia z afisza sztuki krytykującej i degradującej rzekomo ich działania podczas konfliktu zbrojnego oraz obrażającej uczucia patriotyczne. Pojawiły się groźby śmierci pod adresem autora, wezwania do bojkotu, obietnice zablokowania projektu, który współrealizował znany węgierski reżyser András Urbán. W odpowiedzi wspierające Neziraja Stowarzyszenie Artystów Teatralnych Kosowa zmobilizowało policję, a sami jego przedstawiciele sprzeciwili się tym próbom kontroli wypowiedzi artystycznej nie tylko werbalnie, ale i fizycznie, po prostu poprzez swą obecność w Teatrze Narodowym w Prisztinie. Ostatecznie widzowie mogli zapoznać się z materiałem i nie towarzyszyły temu większe incydenty.

47. Dominika Kozera, Mity odkryte na nowo - wspótczesny przekład mitów na przykładzie twórczości Olgi Tokarczuk i Margaret Atwood, w: Trwała obecność mitu w literaturze i kulturze, red. Marzena Karwowska, Mateusz Grabowski, Kamila Żukowska, Wydawnictwo Uniwersytetu Łódzkiego, Łódź 2016, s. 165. 


\section{Podsumowanie}

Binarne opozycje, które wyznaczają podstawowe struktury myślenia ludzkiego, są charakterystyczne dla świata mitycznego, ale konstytuują też kulturę współczesną. Claude Lévi-Strauss postulował jednolitość kultury ludzkiej oraz podkreślał, że umysłowość społeczności tradycyjnych i współczesnych to jedynie warianty umysłu wspólnego dla całej ludzkości ${ }^{48}$. Mitologia z powodzeniem funkcjonuje jako tworzywo fabularne i przedmiot artystycznych transformacji. Treści z tego rezerwuaru podlegają wciąż transferowi zachodzącemu pomiędzy poszczególnymi aktorami pola kulturowego (poprzez transtekstualność, kontakty nawiązywane przez autorów, tłumaczy, przenikanie form, tendencji i stylów).

Mit to pojęcie stale zmieniające swoją konfigurację historyczno-kulturową, a sposoby jego manifestowania się w wyobraźni twórczej nie są tożsame. Można jednak wyodrębnić pewne cechy wspólne zaprezentowanej tu twórczości autorstwa Ivany Sajko, Ljubomira Đurkovicia i Jetona Neziraja. Artystów tych łączy zaangażowanie, eksperymentowanie oraz wyrażanie obaw na temat kondycji ludzkości. Przenoszą oni także do własnego kręgu kultury wyselekcjonowane elementy mitologicznego budulca i poddając je rozmaitym zabiegom, doprowadzają do rodzenia się nowego sensu.

Gesty artystyczne autorów, polegające na spięciu treści dramatu klamrą mitu, pozwalają ukazać newralgiczne punkty codzienności (takie jak konflikty zbrojne, tranzycja i transformacja, trauma powojenna), a jednocześnie współtworzą nowy dyskurs metadramatyczny i metateatralny. Selekcję dzieł antycznych i poddawanie ich szeregowi procesów „tekstualnej transcendencji” ${ }^{\text {"49 }}$ można uznać za „wyraz postmodernistycznego podejścia do tekstów kultury pojmowanych każdorazowo jako moduł większej sieci asocjacji transtekstowych, penetrujący głównie zagadnienia estetyczne i psychologiczne" 50 .

Nie istnieje czyste niezapośredniczone dzieło, a każdy tekst jest mozaiką i ujawnia swoją dialogiczną strukturę. Również przedstawione tu dramaty powstały zgodnie z tą zasadą i wchłonęły w siebie inne treści. Są one wynikiem przeniesienia, zmiany oraz konfrontacji rozmaitych znaczeń, tradycji i poetyk. Proces ten nosi znamiona transgresji, która „pomaga nam dostrzec i zintegrować

48. Claude Lévi-Strauss, Myśl nieoswojona, za: Anna Szabelska, Claude Lévi-Strauss i strukturalna analiza mitu a przyczynek do badań kognitywnych, „Via Mentis”, 2012, nr 1, s. 99.

49. Określenie Gerarda Genette’a w Palimpsesty. Literatura drugiego stopnia, przeł. Tomasz Stróżyński, Aleksander Milecki, Słowo/obraz terytoria, Gdańsk 2014.

50. Małgorzata Budzowska, Wprowadzenie, w: Małgorzata Budzowska, Sceniczne metamorfozy mitu. Teatr polski XXI wieku w perspektywie kulturowej, Wydawnictwo Uniwersytetu Łódzkiego, Łódź 2018, s. 15. 
inność, pomaga nadal silnie przeżywać sztukę oraz sprawia, że pozostaje ona aktualna i dotkliwa" ${ }^{51}$.

Ujęte w tym przeglądzie utwory stanowią nieszablonowe przykłady niezwykle udanego „wynegocjowania” warunków wykorzystania tradycyjnej wersji mitu w nowym przekazie. Sens takich prefiguracji, transpozycji i reinterpretacji leży w zmianie lokalizacji elementów, ich aktualizacji i przemodelowaniu, aby przekraczały stare i współtworzyły nowe jakości.

Twórczość dramatopisarzy zogniskowana wokół mitologii w znacznym stopniu urozmaica i wzbogaca także produkcję teatralną. W zestawieniu tym wspomniano o przykładach transformacji tekstów w spektakle, które powstają w wyniku transgranicznej kooperacji lub mają transkulturowy rys. Ujawniają one wszechstronność w podejściu współczesnych artystów teatru do tkanki mitycznej. Aspekt ten powinien jednak zostać opracowany osobno z uwzględnieniem bardziej rozbudowanego komentarza. Istnieją liczne przykłady zapowiadające wartościowe wyniki takiego badawczego przedsięwzięcia.

51. Agnieszka Wolny-Hamkało, Transgresje, dygresje, wstęp, w: Transgresje. Antologia, red. Agnieszka Wolny-Hamkało, Towarzystwo Aktywnej Komunikacji, Wrocław 2014, s. 5. 